\title{
Effect of physical and chemical treatments on breaking the seed dormancy of Caesalpinia bonduc (L.) Roxb.
}

\author{
Jeya Rathi J, Sasirekha R \& Ranjith Kumar R \\ Department of Botany, Madras Christian College (Autonomous - Affiliated to University of Madras), Chennai 600 059, Tamil Nadu, India \\ *Email: jeyarathi.j@mcc.edu.in
}

\section{ARTICLE HISTORY}

Received: 14 December 2020

Accepted: 06 March 2021

Available online: 01 July 2021

\section{KEYWORDS}

Acid scarification

Chemical treatment

Growth hormones

Mechanical scarification

Physical treatment

Seed dormancy

\begin{abstract}
Caesalpinia bonduc (L.) Roxb. is a medicinal plant belonging to the family Caesalpiniaceae was used for the present study. It is a prickly shrub widely distributed all over the world. Keeping the economic and social medicinal uses of $C$. bonduc seeds are being used widely in Folk, Ayurvedha, Siddha, Unani medicines to treat skin disease, eyesores, cancer, asthma, tuberculorosis, fever, toothaches etc. The aim of this study is to determine the requirements for breaking seed dormancy and germination of $C$. bonduc. The germination is prevented due to hard seed coat. $C$. bonduc seeds were experimented with various physical and chemical treatments to break the dormancy. The seeds were subjected to various treatments like mechanical scarification, dry heat method, light, hot water, acid scarification, inorganic compounds, plant growth regulators etc. The seeds treatment with mechanical scarification at 50, 40 and 30 seconds showed $100 \%, 80 \%$ and $10 \%$ of germination, whereas no changes was observed in dry heat. White light treatment showed $100 \%$ germination at $48 \mathrm{hrs}$, whereas darkness and red light showed least germination of about $10 \%$. The hot-water treatment showed $100 \%$ germination. In chemical treatments, concentrated sulphuric acid scarification showed highest germination percentage, whereas lowest germination was found in nitric acid. Among the plant growth regulators, Gibberellic acid showed $100 \%$ germination whereas 2 -isopentyl adenine showed least germination of $10 \%$ at $50 \mathrm{ppm}$. Results of this study prove that mechanical scarification was the most effective treatment to overcome dormancy of seeds in C. bonduc.
\end{abstract}

\section{Introduction}

Forest cover on earth support countless species as well as human livelihoods. Forest covers $30 \%$ of the land. Forests are the most biologically diverse and ecologically complex of terrestrial ecosystems that are disappearing at alarming rates. The trees frequently have viable seeds of low life expectancy or seeds of dormant nature. The average dormancy period of Caesalpinia bonduc seeds has a longer period, the reason may be due to soil, climate and other factors. The seed dormancy is a block to the completion of germination of an intact viable seed under favourable conditions (1-5).

The term dormancy means seeds will not germinate under unfavourable conditions of temperature, moisture and light. The seed dormancy is under five classes such as physiological, morphological, morpho-physiological, physical and combinational dormancy was understood (6). A seed is a small embryonic plant enclosed in a covering called the seed coat. Seeds of different tree species germinate at different time duration of the year. Keeping in mind the economic, social, medicinal and ecological importance, the seed dormancy have to be broken to induce germination. Caesalpinia bonduc (L.) Roxb. is a prickly shrub widely distributed all over the world especially in India including Andaman and Nicobar islands and Sri Lanka. The leaves are bipinnate. Flowers produced in dense terminal racemes and the fruits are brown and downy, bracts squarrose, linear, acute, reaching $1 \mathrm{~cm}$ long. Pods shortly stalked, oblong, $4.5 \mathrm{~cm}$, densely armed with wiry prickles. The hard and shiny seeds are 1-2, oblong, up to $1.3 \mathrm{~cm}$ long green turning grey.

It is widely distributed in tropical and subtropical regions of Asia and is abundant in Western Ghats. The different parts of the plant is used in popular indigenous system of medicine like folk medicines, Ayurveda, Siddha, Unani and Homoeopathy due to its high medicinal value for the treatment of various diseases. It has been reported that the seeds possess anti diarrhoeal, anti filarial, antiviral, antibacterial, anti microbial, anti fungal, anti diabetic, anti tumar, 
analgesic, anti inflammatory, immunomodulatory, adoptogenic, anticonvulsant, antipasmodie, nootropic, antimocbic, diuretic properties (7-12). However, $C$. bonduc shows poor germination and low seedlings establishment. The information on seed biology and germination behavior and dormancy pattern of this valuable species is lacking. Therefore, the purpose of the study is to investigate the aspects of germination ecology such as fruit-seed characteristics and germination employing various physical and chemical treatments to standardise the best treatment to break dormancy (13).

\section{Materials and Methods}

\section{Study area}

Madras Christian College campus, Chennai, Tamil $\mathrm{Nadu}$, India is located at $12^{\circ} 55^{\prime} \mathrm{N}$ latitude and $80^{\circ} 7^{\prime} \mathrm{E}$ longitude. The average elevation of the campus is about $30 \mathrm{~m}$ above sea level (14).

\section{Source of Seeds}

The healthy, viable, uniform sized seeds were collected from the campus. Herbarium specimen has been prepared and deposited in the Laboratory of Ecology (Ref. No. JR 1012), Madras Christian College, Chennai.

\section{Surface Sterilization}

The seeds were sterilized with two chemical disinfectants namely $1 \% \mathrm{HgCl}_{2}$ for $5 \mathrm{~min}$, followed by 3 min exposure to $70 \% \mathrm{C}_{2} \mathrm{H}_{5} \mathrm{OH}$. $1 \% \mathrm{HgCl}_{2}$ is prepared by dissolving $1 \mathrm{gm}$ of $\mathrm{HgCl}_{2}$ in $100 \mathrm{ml}$ of distilled water. The petridishes used for the experimental purpose was first sterilized and lined with Whattman filter paper. The treatment seeds were watered with $5 \mathrm{ml}$ distilled water once in two days throughout the germination period.

\section{Moisture Content of Fruits and Seeds}

A batch of 10 leguminous pods and seeds were taken and fresh weight of the individual pods and seeds were analyzed using an electronic balance. The fruits were then dried in a hot air oven at $80^{\circ} \mathrm{C}$ for about 12 hours and the dry weight of the fruits were also calculated using the formulae: (15).

Percentage $(\%)$ of moisture content $=$ FW $-\mathrm{DW} \times 100$

$$
\text { FW }
$$

Where, FW - Fresh weight; DW - Dry weight

\section{Germination Percentage}

The germination percentage of the seeds of $C$. bonduc in each treatment in our present study was calculated by the formula (16).

Germination percentage $(\%)=$

$$
\text { No. of Seeds Germinated × } 100
$$

Total number of seeds

\section{Seed Viability}

Test for seed viability was carried out on a weekly basis. This test was done to ensure that the seeds to be used for the experiment were viable and of high quality. Seeds was soaked overnight in beaker containing water. Imbibed seeds were then cut into equal halves using a sharp blade and immersed in $0.1 \%$ (TTC) solution. Observation was made at hourly intervals and gradual changes in the color of seed halves were noted. The seed halves which turned pink were viable/Tetrazolium positive and those that did not show any color change were non-viable/Tetrazolium negative and it does not germinate in less scarification action of microbes insects. The results were tabulated and the percentage of viability was calculated (16). The seed viability test was done in the initial stage of the work and the average number of seeds used for each experiment was 10 .

\section{Physical Treatments}

\section{Mechanical Scarification}

The seed batches were subjected to mechanical scarification by rubbing against the floor for 10, 20, 30, 40, 50 and $60 \mathrm{sec}$ duration (17).

\section{Dry Heat Scarification}

The seeds were exposed to dry heat in a hot air oven maintained at $10^{\circ} \mathrm{C}, 20^{\circ} \mathrm{C}, 30^{\circ} \mathrm{C}, 40^{\circ} \mathrm{C}, 50^{\circ} \mathrm{C}$ and $60^{\circ} \mathrm{C}$ for 5 min along with a control maintained at room temperature (18).

\section{Leaching}

The seeds were mechanically scarified by rubbing on the ground. Batches of 10 seeds of were pre-soaked in distilled water for 12, 24, 36 and 48 hrs duration under lab condition (19).

\section{Light Treatment}

The seeds were subjected to different radiation like white light, red light, far red and complete darkness in the seed germination chamber. The respective lamps are used in the germination chambers for about 12, 24, 36 and 48 hrs duration (20).

\section{Hot water Scarification}

Ten seeds were subjected to hot water scarification by heating the seeds over electric hot water heater. The different temperature is reached by turning the temperature knob and the required temperature is maintained by adding cold water and hot water displaced using a small breaker. The seeds are treated at varying temperatures of $60^{\circ} \mathrm{C}, 70^{\circ} \mathrm{C}, 80^{\circ} \mathrm{C}$, $90^{\circ} \mathrm{C}$ and $100{ }^{\circ} \mathrm{C}$ for about $30 \mathrm{~min}(21)$.

\section{Chemical Treatments}

\section{Acid Scarification}

\section{Sulphuric acid Treatment $\left(\mathrm{H}_{2} \mathrm{SO}_{4}\right)$}

Three batches of 15 seeds were pretreated with concentrated $\left(\mathrm{H}_{2} \mathrm{SO}_{4}\right)$ for varying durations of time of $10,20,30,40,50$ and 60 min respectively. After the acid treatment, the treated seeds were subjected to leaching in running water. The seeds were then kept separately in petriplates for observation (22).

\section{Nitric acid $\left(\mathrm{HNO}_{3}\right)$}

Three batches of 15 seeds were pretreated with concentrated $\mathrm{HNO}_{3}$ for varying duration of 10, 20, 30, 40, 50 and $60 \mathrm{~min}$ to test their germination inability. 
After the acid treatment, the treated seeds were subjected to leaching in running water respectively.

\section{Hydrochloric acid (HCl)}

Three batches of 15 seeds were pretreated with concentrated $\mathrm{HCl}$ for varying duration of $10,20,30$, 40, 50 and $60 \mathrm{~min}$. After the acid treatment, the seeds were subjected to leaching in running water and kept for germination in petriplates respectively.

\section{Inorganic Compounds}

\section{Potassium nitrate $\left(\mathrm{KNO}_{3}\right)$}

The different concentrations of $\mathrm{KNO}_{3}$ such as $0.25 \mathrm{M}$, $0.5 \mathrm{M}, 1.0 \mathrm{M}, 1.5 \mathrm{M}$ and $2.0 \mathrm{M}$ were prepared with distilled water. The seeds were rubbed against the concrete floor, then soaked in the respective concentrations of potassium nitrate for a day and control (23).

\section{Ammonium nitrate $\left(\mathrm{NH}_{4} \mathrm{NO}_{3}\right)$}

The different concentrations of $\mathrm{NH}_{4} \mathrm{NO}_{3}$ such as $0.1 \%$, $0.2 \%, 0.3 \%, 0.4 \%$ and $0.5 \%$ were prepared by adding $0.1 \mathrm{gm}, 0.2 \mathrm{gm}, 0.3 \mathrm{gm}, 0.4 \mathrm{gm}$ and $0.5 \mathrm{gm}$ in $100 \mathrm{ml}$ of distilled water. The seeds were rubbed against the concrete floor, then soaked in the respective concentrations of $\mathrm{NH}_{4} \mathrm{NO}_{3}$ for a day and control (24).

\section{Plant Growth Regulators}

\section{Gibberellic acid ( $\left.\mathrm{GA}_{3}\right)$}

The different concentrations of GA such as $10 \mathrm{ppm}$, 25 ppm, 50 ppm, 75 ppm and 100 ppm were prepared with distilled water. The seeds were rubbed against the concrete floor, then soaked in the respective concentrations of GA for a day and control.

\section{2-Isopentyl adenine}

The different concentrations of 2- Isopentyl adenine such as 10 ppm, 25 ppm, 50 ppm, 75 ppm and 100 ppm respectively were prepared with distilled water. The seeds were rubbed against the concrete floor, then soaked in the respective concentrations of 2Isopentyl adenine for a day and control. The growth hormone has no specific reaction in breaking up of seed dormancy in a very low ratio.

\section{Statistical Analysis}

All analyses were carried out in triplicate and the results reported as mean \pm Standard Deviation (SD). The Student's $t$ test and ANOVA was used to compare the means between three groups.

\section{Results and Discussion}

\section{Seed Viability, Fresh Weight, Dry Weight and Moisture Content Percentage}

The percentage of seed viability in $C$. bonduc was found to be $75 \%$. The average fresh weight of the pod was about $4.97 \mathrm{gm}$ while the average dry weight was about $4.81 \mathrm{gm}$. The average moisture content percentage of the pod was found to be $3.8 \%$ (Table 1 ). The average fresh weight and dry weight of the seed were analyzed (0.48 $\mathrm{gm}$ and $0.44 \mathrm{gm})$. The average moisture content percentage of the seed is noted to be 8.02 (Table 2).

\section{Physical treatment}

\section{Mechanical scarification}

The mechanically scarified seeds had significant impact on breaking the dormancy. The seeds that were mechanically scarified for 50, 40 and $30 \mathrm{sec}$ showed $100 \%, 80 \%$ and $10 \%$ germination percentage respectively; whereas the germination percentage of seeds that were mechanically scarified for about 10 and 20 sec doesn't show any germination (Table 3). In the present study, it was observed that mechanically scarified seeds showed very high germination percentage. The study (24) revealed that the seeds mechanical scarification improved seed germination and seedling growth. Seeds mechanically scarified with sandpaper had germination of about $83.3 \%$ respectively in the seeds of Parkia biglobosa. This shows that mechanically scarified may be effective for breaking dormancy and improving the seedling vigour (25).

\section{Dry Heat Treatment}

The seeds treated at different temperatures in hot air oven were found not very effective on breaking the dormancy. The seeds treated at $30^{\circ} \mathrm{C}, 40^{\circ} \mathrm{C}, 50^{\circ} \mathrm{C}, 60$ ${ }^{\circ} \mathrm{C}, 70^{\circ} \mathrm{C}$ and $80^{\circ} \mathrm{C}$ didn't show any significant change in the breaking up of seed dormancy. However, incubating seeds at $30 / 15^{\circ} \mathrm{C}, 40 / 25^{\circ} \mathrm{C}$ and $80{ }^{\circ} \mathrm{C}-100{ }^{\circ} \mathrm{C}$ were ineffective in breaking dormancy in Senna marilandica (6).

\section{Leaching Treatment}

The seeds treated in leaching treatment with water at room temperature showed highest of $100 \%, 80 \%$ and $80 \%$ germination at 72,48 and 36 hrs respectively. No germination was seen at 12 and 24 hrs interval (Table 4).

\section{Light Treatment}

At different light treatments (White light, Red light, Darkness) the seeds showed a highest of $100 \%$ germination at $48 \mathrm{hrs}$ in white light and least germination of $10 \%$ were observed in darkness and red light at the same time interval. Germination percentage was observed to be very low in all light treatments. White light shows better result in all time interval when compared to other light treatments. Among the lights that were used red light favours the germination of seeds next to darkness was observed in the present study (Fig. 1).

\section{Hot Water Treatment}

The seeds treated at different temperatures in hot water bath treatment showed highest of $100 \%, 80 \%$, $40 \%$ and $30 \%$ germination at $100{ }^{\circ} \mathrm{C}, 90{ }^{\circ} \mathrm{C}, 80^{\circ} \mathrm{C}$ and $70{ }^{\circ} \mathrm{C}$ respectively. No germination was seen at $60^{\circ} \mathrm{C}$

Table 1. Moisture content of pods

\begin{tabular}{ccc}
\hline $\begin{array}{c}\text { Fresh weight of } \\
\text { pods (gm) }\end{array}$ & $\begin{array}{c}\text { Dry weight of } \\
\text { pods (gm) }\end{array}$ & $\begin{array}{c}\text { Average moisture content } \\
\text { of pods (gm) }\end{array}$ \\
\hline 4.97 & 4.81 & 3.8 \\
\hline Table 2. Moisture content of seeds & \\
\hline $\begin{array}{c}\text { Fresh weight } \\
\text { of seeds }\end{array}$ & $\begin{array}{c}\text { Dry weight } \\
\text { of seeds }\end{array}$ & $\begin{array}{c}\text { Average moisture content } \\
\text { of seeds }\end{array}$ \\
\hline 0.48 gm & 0.44 gm & 8.02 gm \\
\hline
\end{tabular}


Table 3. Seed germination in response to mechanical scarification in Caesalpinia bonduc (L.) Roxb.

\begin{tabular}{ccc}
\hline Sl. No & $\begin{array}{c}\text { Time } \\
\text { (in seconds ) }\end{array}$ & No. of seeds germinated \\
\hline 1 & 10 & - \\
\hline 2 & 20 & - \\
\hline 3 & 30 & $1.2 \pm 0.71(10)$ \\
\hline 4 & 40 & $8.33 \pm 1.24(80)$ \\
\hline 5 & 50 & $10.33 \pm 0.46(100)$ \\
\hline
\end{tabular}

(Fig. 2). Similar results were observed in an earlier report (26).

\section{Chemical Treatment}

\section{Acid Scarification}

The experimental seeds soaked in concentrated $\mathrm{H}_{2} \mathrm{SO}_{4}$ at different time intervals showed significant difference in seed germination. The treatment promoted seed dormancy breaking in all time intervals. The highest germination percentage of the seeds in different time intervals such as 10,20 , $30,40,50$ and 60 minutes are 10\%, 10\%, 20\%, 30\%, $50 \%$ and $100 \%$ respectively. The germination percentage is highest in seeds soaked for 50 and 60 min (50\% and 100\%) and the lowest germination percentage for seeds treated for $10 \mathrm{~min}, 20 \mathrm{~min}, 30$ min and 40 min (10\%, 10\%, 20\% and 30\%) (Fig. 3). Among these acids used for scarification treatment, concentrated $\mathrm{H}_{2} \mathrm{SO}_{4}$ promoted seed dormancy breaking more significantly than concentrated $\mathrm{HNO}_{3}$, and concentrated $\mathrm{HCl}$. The seeds treated with concentrated $\mathrm{HCl}$ showed very poor or no germination.

Germination percentage analysis of seed germination effect with $\mathrm{HNO}_{3}$ showed similar results in lower time intervals when compared to concentrated $\mathrm{H}_{2} \mathrm{SO}_{4}$. Higher percentage of $100 \%$ result was significantly seen in seed soaked for 50 min in concentrated $\mathrm{H}_{2} \mathrm{SO}_{4}(25)$.

Table 4. Seed germination in response to leaching in Caesalpinia bonduc (L.) Roxb.

\begin{tabular}{ccc}
\hline Sl. No & $\begin{array}{c}\text { Time } \\
\text { (in hrs ) }\end{array}$ & No. of seeds germinated \\
\hline 1 & 12 & - \\
\hline 2 & 24 & - \\
\hline 3 & 36 & $8.33 \pm 1.24(80)$ \\
\hline 4 & 48 & $8.33 \pm 1.24(80)$ \\
\hline 5 & 72 & $10.33 \pm 0.46(100)$ \\
\hline
\end{tabular}

\section{Inorganic compounds}

The treatment with $\mathrm{KNO}_{3}$ didn't have much significance on the germination of $C$. bonduc seeds in all concentrations. The highest germination percentage was observed in $0.5 \mathrm{M}$ concentration (40\%). Whereas, other concentration with $\mathrm{KNO}_{3}$ were noted to be $0 \%$ respectively. Like $\mathrm{KNO}_{3}, \mathrm{HNO}_{3}$ also responded only in low concentration (1M) of $10 \%$, the rest of the concentrations $(0.25 \mathrm{M}, 0.5 \mathrm{M}$, $1.5 \mathrm{M}$ and $2 \mathrm{M}$ ) didn't show any sign of germination (Fig. 4). When comparing both the chemical treatments, no significant effect on breaking the seed dormancy of Caesalpinia was observed.

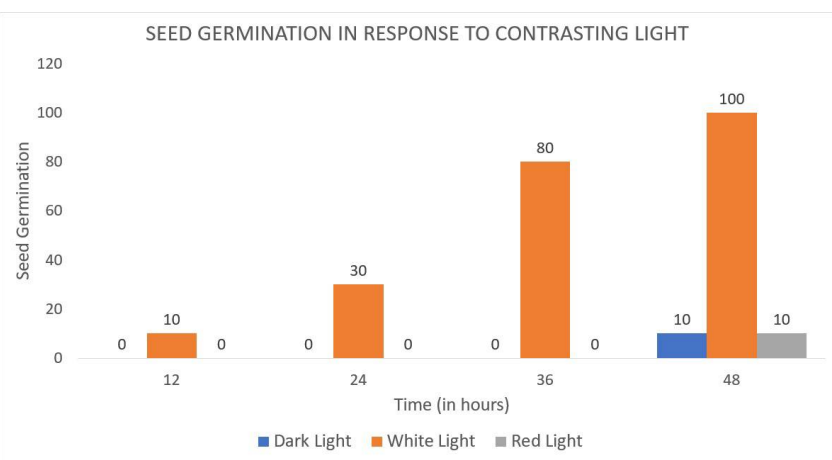

Fig. 1. Seed germination in response to contrasting light conditions ( Dark light, White light and Red light ) of Caesalpinia bonduc (L.) Roxb.

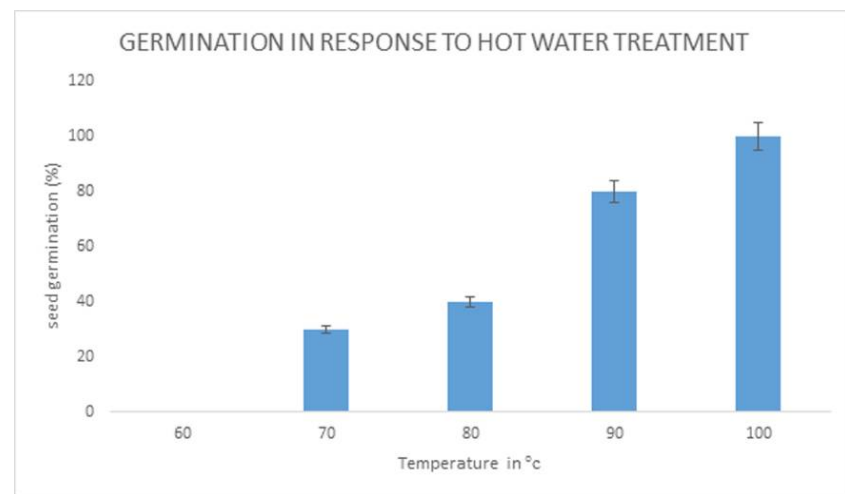

Fig. 2. Germination in response to hot water treatment in Caesalpinia bonduc (L.) Roxb. seeds.

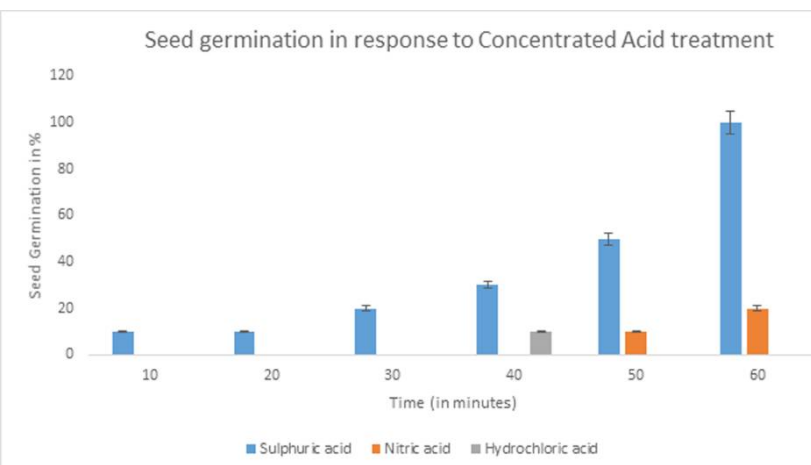

Fig. 3. Response to concentrated acids in seed germination of Caesalpinia bonduc (L.) Roxb.

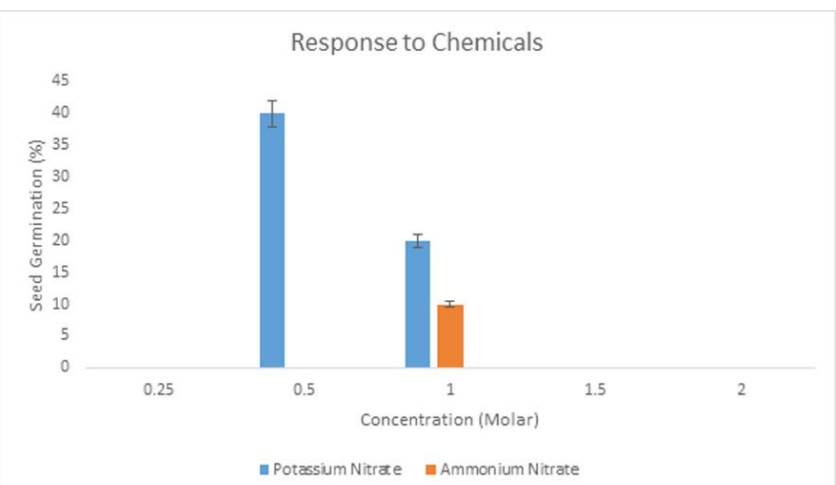

Fig. 4. Effect of chemicals $\left(\mathrm{KNO}_{3}\right.$ and $\left.\mathrm{NH}_{4} \mathrm{NO}_{3}\right)$ on seed germination of Caesalpinia bonduc (L.) Roxb.

\section{Plant growth regulators}

Observations were made in breaking the seed dormancy of $C$. bonduc in plant growth hormones by soaking the seeds for about $24 \mathrm{hrs}$ in both $\mathrm{GA}_{3}$. The 


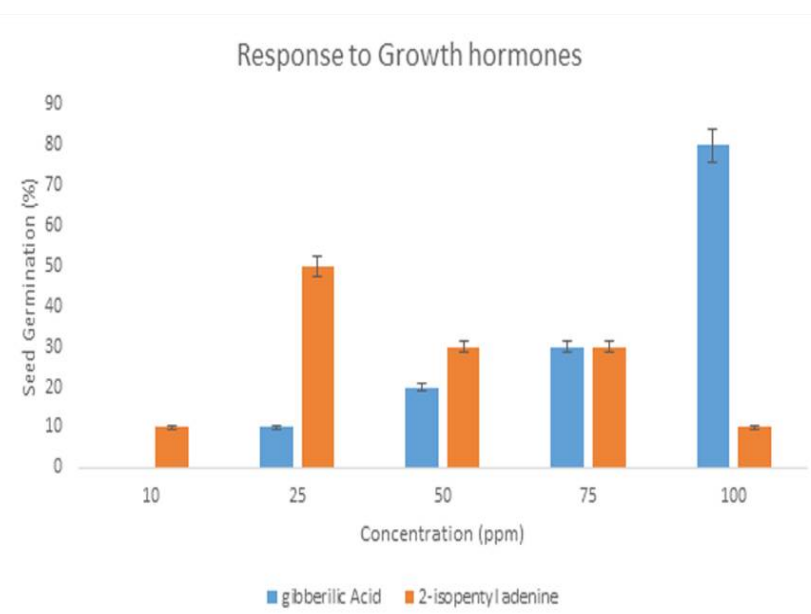

Fig. 5. Effect of growth hormones on seed germination of Caesalpinia bonduc (L.) Roxb.

highest germination percentage was percentage at 50 ppm of $\mathrm{GA}_{3}(60 \%)$. The germination percentage at 10 ppm, 25 ppm, 75 ppm and 100 ppm were 10\%, 20\%, $30 \%$ and $10 \%$ respectively (Fig. 5). When the rate of seed germination of both the growth regulators were compared and analysed 2ip showed about 10\% less germination at $50 \mathrm{ppm}$ concentration than $\mathrm{GA}_{3}$. Similar results were obtained in Echinacea angustifolia (25). General uses of both the growth hormones were found in this growth of plants but no specific use is mentioned in breaking up of seed dormancy.

\section{Conclusion}

The seeds of the wild spiny shrub Caesalpinia bonduc (L.) Roxb. are dispersed by wind when the mature pods dry up. The seeds were experimented with various physical and chemical treatments to break the seed dormancy. The seeds have physical dormancy due to the hard impermeable seed coat. As it prefers to both shade and direct sunlight, it thereby reduces germination percentage. This study provides data about the germination of seeds which will be useful in regeneration of this species. The study develops an efficient method to break the dormancy. The treatment was given to break the seed coat dormancy. Among the different treatment methods, the hot water scarification of seeds showed $100 \%$ germination and rapid growth was significantly observed. This wild spiny plant is not only ecologically important but also serves as a source of medicine and livelihood. So it is important to conserve such wild species. More intense investigation on the reproductive biology of $C$. bonduc is the need of the hour for conservation and regeneration.

\section{Acknowledgements}

The authors are thankful to the Head of the Department of Botany and the Principal, Madras Christian College (Autonomous), Chennai, Tamil Nadu for providing the necessary infrastructure and we also extend our thanks to the Assistant Professor of
Botany Dr. Selva Singh Richard for plant identification.

\section{Authors' contributions}

All authors have read and approved the final manuscript. As the corresponding author, I certify that the submission is an original work and is not under review at any other publication, nor has it previously been submitted to any other journal.

\section{Conflict of interests}

Authors do not have any conflicts of interests to declare.

\section{References}

1. Hilhorst HWM. A critical update on seed dormancy. I. Primary dormancy. Seed Science Research. 1995;5:61-73. https://doi.org/10.1017/S0960258500002634

2. Bewley JD. Seed germination and dormancy. Plant Cell 1997a:9:1055-66. https://doi.org/10.1105/tpc.9.7.1055

3. Li BL, Foley ME. Genetic and molecular control of seed dormancy. Trends in Plant Science. 1997;2:384-89. https://doi.org/10.1016/S1360-1385(97)90053-4

4. Finch-Savage WE., Leubner-Metzger G. Seed dormancy and the control of germination. New Phytol. 1997;171:505-23. https://doi.org/10.1111/j.1469-8137.2006.01787.x

5. Batlla D, Benech-Arnold RL. Predicting changes in dormancy level in natural seed soil banks. Plant Mol Biol. 2010;73:3-13 https://doi.org/10.1007/s11103-010-9601-z

6. Baskin CC, Baskin JM. Ecology, biogeography and evolution of dormancy and germination, Annals of Botany. CC Baskin; JM Baskin. (Eds.), Academic Press, San Diego, California. 1998; https://doi.org/10.1006/anbo.2000.1238

7. Gupta M, Mazumder UK, Kumar RS, Sivakumar T, Vamsi ML. Antitumor activity and antioxidant status of Caesalpinia bonduc against Ehrlich ascites Carcinoma in Swiss albino mice. Journal of Pharmacological Sciences. 2004;94(2):177- 84

8. Singh V, Raghav PK Review on pharmacological properties of Caesalpinia bonduc L. Int J Med Arom Plants. 2012; 2(3):514-30.

9. Khan MR. Seed dormancy in Caesalpina bonduc (L) Roxb. Bulletin of Pure and Applied Sciences. 34-B -Botany. 2015; No.1-2:25-30.

10. Danthu PM, Rousesel M. Dia and Sarr A. Effect of different pretreatment on the germination of Acacia senegal seeds. Seeds Science and Technology. 1992; 20:111-17.

11. Grover JK, Yadav S, Vats V. Medicinal plants of India with antidiabetic potential. J Ethnopharmacol. 2002;81-100.

12. Kannur DM, Hukkeri VI, Akki KS. Antidiabetic activity of Caesalpinia bonduc seeds extracts in rats, Fitoterapia. 2006;77: 46.

13. Leónie Bentsink, Maarten Koornneef. Seed Dormancy and Germination. The American Society of Plant Biologist. 2008;6:14. https://dx.doi.org/10.1199\%2Ftab.0119

14. Meher-Homji VM, Gadgil M. Ecological Diversity. In: Conservation in Developing Countries: problems and prospects, JC Daniel; JS Serrao (Eds.). Proceedings of the Centenary Seminar of the Natural History Society, Bombay Natural History Society, Oxford University Press. 1990. https://www.researchgate.net/publication/288947818.

15. Bewley JD, Black M. Physiology and biochemistry of seeds, Springer-Verlag, New York. 1982. https://doi.org/10.1007/9783-642-68643-6

16. Sanjana Julias Thilakar and Jeya Rathi J. A study on the effect of physical and chemical treatments on breaking the 
dormancy of Adenanthera pavonina L. seeds. Journal of Natural Products and Plant Resources. 2013;3(5):55-63.

17. Porter RH. Recent developments in seed technology. The Botanical Review. https://doi.org/10.1007/BF02861694

18. Jeffery DJ, Holmes PM, Rebelo AG. Effects of dry heat on seed germination in selected indigenous and alien legume species in South Africa. 1988;54(1):28-34 https://sciencedirect.com/science/article/pii/S0254629916313588

19. Rincker CM, Agron J.Breaking of Dormancy in the Seeds of Astragalus mongholicus Bunge (Leguminosae) 1954;146:247-50. https://doi.org/10.1016/S0176-1617(11)82070-5

20. Zohre Zoghi, Davud Azadfar, Yahya Kooch. The effect of different treatments on seeds dormancy breaking and germination of Caspian Locust (Gleditschia caspica) Tree. Annals of Biological Research. 2011;2(5):400-06. http://scholarsresearchlibrary.com/archive.html

21. Brant RE, Mckee GW, Cleveland RW. Effect of chemical and physical treatment on hard seed of Penngift Crownvetch. Crop Science. 1971;11:1-6 https://doi.org/10.2135/cropsci1971.0011183X001100010001x

22. Abdenour Kheloufi1, LahouariaMouniaMansouri, FaizaZinebBoukhatem. Application to improve seed germination of three Acacia spp. Foresta. 2017;3:1-10 https://www.researchgate.net/deref/

23. Sharma Sr, Dwivedi Sk, Swarup.D. Hypoglycemic, anti hyperglycemic and hypolipidemic activities of Ceasalpinia bonduc seeds in rats. J Ethanopharmacol.1997; 58:39-44. https:// doi.org/10.1016/s0378-8741(97)00079-2

24. Okunlola AI, Adebayo RA, Orimogunje AD. Methods of breaking seed dormancy on germination and early seedling growth of African locust bean (Parkia biglobosa) JACQ.) Benth Journal of Horticulture and Forestry. 2011;3(1):1-6. https://doi.org/10.5897/JHF.9000076

25. Biswas TK, Bandopadhyay S, Mukherjee B, Sengupta BR. Oral hypogiycaemic effect of Caesalpinia bonducella, International Journal of Pharmacognosy. 2011;35(4):261. https://doi.org/10.1076/phbi.35.4.261.13304

26. Chakrabarti S, Biswas TK, Rokeya B, Ali L, Mosihuzzaman M, Nahar N, Khan AK. and Mukherjee B. Advanced studies on the hypoglycemic effect of Caesalpinia bonducella F. in type 1 and 2 diabetes in Long Evans rats. J Ethnopharm. 2003;84:41-46. https://doi.org/10.1016/s0378-8741(02)00262-3

\section{Additional information}

Peer review information: Plant Science Today thanks Sectional Editor and the other anonymous reviewers for their contribution to the peer review of this work.

Reprints and permissions information is available at

https://horizonepublishing.com/journals/index.php/PST/open_access_policy

Publisher's Note: Horizon e-Publishing Group remains neutral with regard to jurisdictional claims in published maps and institutional affiliations.

To cite this article: Jeya Rathi J, Sasirekha R, Ranjith Kumar R. Effect of physical and chemical treatments on breaking the seed dormancy of Caesalpinia bonduc (L.) Roxb. Plant Science Today. 2021;8(3):572-577. https://doi.org/10.14719/pst.2021.8.3.1049

Plant Science Today, published by Horizon e-Publishing Group, is covered by Scopus, Web of Science, BIOSIS Previews, Clarivate Analytics, etc. See https://horizonepublishing.com/journals/index.php/PST/indexing_abstracting 